\title{
Short-term infusion of interleukin-6 does not induce insulin resistance in vivo or impair insulin signalling in rats
}

\author{
V. Rotter Sopasakis ${ }^{1}$ B.-M. Larsson ${ }^{2}$ A. Johansson ${ }^{1}$ A. Holmäng ${ }^{2}$ U. Smith ${ }^{1}$ \\ ${ }^{1}$ The Lundberg Laboratory for Diabetes Research, Department of Internal Medicine, The Sahlgrenska Academy at Göteborg \\ University, Sahlgrenska University Hospital, Göteborg, Sweden \\ 2 The Wallenberg Laboratory, Institute of Cardiovascular Disease, The Sahlgrenska Academy at Göteborg University, Göteborg, \\ Sweden
}

\begin{abstract}
Aims/hypothesis. Interleukin-6 has been implicated in the insulin resistance associated with obesity and impaired glucose tolerance. Previous studies in vitro have shown that IL-6 rapidly (1-2 h) impairs cellular insulin signalling and action through an increased expression of suppressor of cytokine signalling (SOCS)3 . In the present study, IL-6 or saline was infused in rats that were simultaneously in a state of hyperinsulinaemia. Muscle, liver and adipose tissue were excised after $2 \mathrm{~h}$ to examine potential effects on insulin signalling or gene expression.

Methods. The rats were infused with IL-6 or saline during a euglycaemic-hyperinsulinaemic clamp and the glucose infusion rate was measured after 90 to 120 min. Signal transducer and activator of transcription (STAT)3 phosphorylation and insulin-stimulated tyrosine phosphorylation of the insulin receptors and IRS were measured with immunoblotting and gene expression through real-time PCR.

Results. No inhibitory effect of IL-6 on insulin-stimulated whole-body glucose uptake was seen in spite of
\end{abstract}

high circulating levels of IL-6 $(0.85 \pm 0.08 \mathrm{nmol} / \mathrm{l})$. Tyrosine phosphorylation of the insulin receptors and IRS was also unchanged in the liver, skeletal muscles and adipose tissue. However, tyrosine phosphorylation of STAT3 was increased in all tissues, showing that IL-6 signalling was activated. IL- 6 mRNA tended to increase, while GLUT4, peroxisome proliferatoractivated receptor- $\gamma$ coactivator-1 (PGC-1) and adiponectin gene expression were unchanged.

Conclusions/interpretation. Infusion of IL-6 for $120 \mathrm{~min}$ in rats during euglycaemic-hyperinsulinaemic conditions did not alter the effect of insulin on whole-body glucose homeostasis, plasma adiponectin levels or insulin signalling in target tissues. Thus, the acute effects of IL-6, associated with SOCS-3 induction, do not lead to whole-body insulin resistance. These data further underscore the importance of the chronic, and potentially tissue-specific effects of IL-6 on insulin signalling and action.

Keywords Adipose tissue - Glucose uptake - Insulin · Insulin action · Insulin signalling · Interleukin-6 •

Liver $\cdot$ Muscle $\cdot$ Suppressors of cytokine signalling
Received: 8 April 2004 / Accepted: 18 July 2004

Published online: 17 November 2004

C Springer-Verlag 2004

\section{U. Smith (}

The Lundberg Laboratory for Diabetes Research, Department of Internal Medicine,

The Sahlgrenska Academy at Göteborg University, Sahlgrenska University Hospital, 41345 Göteborg, Sweden

E-mail: ulf.smith@medic.gu.se

Tel.: +46-31-3421104, Fax: +46-31-829138

Abbreviations: PGC-1, peroxisome proliferator-activated receptor- $\gamma$ coactivator- 1 - SOCS, suppressors of cytokine signalling - STAT, signal transducers and activators of transcription

Conflict of interest: None

\section{Introduction}

Interleukin-6 plays an important role in the acute immune response $[1,2]$. In addition, it has recently been implicated in the insulin resistance associated with obesity, impaired glucose tolerance and diabetes $[3,4$, $5,6]$. The circulating levels of IL-6 are elevated in these conditions $[6,7]$ and IL-6 was also shown in prospective studies to be an independent predictor of risk of developing type 2 diabetes irrespective of the amount of body fat [8].

Adipose tissue accounts for 15 to $35 \%$ of the total circulating IL-6 levels, making this tissue a major site for IL-6 production and secretion [3, 9]. In addition to secreting IL-6 and other cytokines, the adipocytes are 
also target cells, as (i) they have been shown to express the different components of IL-6 signalling, such as IL-6 receptors, gp130 and signal transducers and activators of transcription (STATs), and (ii) this signalling system has been shown to be activated upon IL-6 stimulation [10, 11]. Other target tissues for insulin action, such as the liver and skeletal muscle, also express the various components of the IL-6 signalling system $[12,13,14,15]$, supporting the possibility that whole-body insulin sensitivity may be modulated by IL-6. This possibility was corroborated by recent findings that exogenous administration of IL-6 induces insulin resistance in adipose and liver cells $[11,16,17$, 18]. HepG2 cells, as well as primary mouse hepatocytes, had decreased tyrosine phosphorylation of IRS-1 in response to insulin as well as reduced protein kinase B activation in the presence of IL-6 [17]. This effect of IL-6 was attributed to the concomitantly and transiently increased expression of suppressors of cytokine signalling (SOCS-3) [18]. The SOCS-3 gene is also transiently activated in response to IL-6 in muscle cells [19], as well as in adipose cells [16], reaching a peak within 120 min followed by a rapid decline to basal levels (unpublished observations). Surprisingly, insulin also increases SOCS-3 expression with a similar time-course to that of IL- 6 and this has been shown to reduce the intracellular signalling of this hormone [20]. Thus, SOCS-3 may play a role in the impaired insulin signalling seen after IL-6 administration and in conjunction with chronic hyperinsulinaemia [20].

In addition to the effects on upstream signalling of insulin, SOCS-3 has also been found to initiate ubiquination and degradation of IRS-1 in HEK293 cells [21]. However, in contrast to the effects of IL-6 in liver cells, short-term (10-120 $\mathrm{min})$ exposure to IL-6 does not significantly reduce the tyrosine phosphorylation of the insulin receptor or the IRS molecules in adipose cells in response to insulin, although SOCS-3 mRNA levels are increased $[11,16]$ (unpublished observations). However, long-term exposure $(\geq 24 \mathrm{~h})$ does lead to insulin resistance through the down-regulation of IRS-1 and GLUT4, and this is associated with reduced insulin-stimulated glucose transport $[11,16]$. In addition, IL-6 has been found to reduce the gene expression and secretion of adiponectin in both 3T3-L1 [22, 23] and human adipocytes [24], and this is another mechanism whereby IL-6 can impair insulin sensitivity.

In addition to the large pool of data supporting a role for IL-6 in insulin resistance, as well as directly demonstrating that this cytokine impairs insulin signalling [11, 16, 17, 18], IL-6 ablation in mice has provided evidence for other effects. Wallenius and co-workers [25] reported that IL-6 ${ }^{-/-}$mice developed maturity-onset obesity, with elevated circulating triglyceride levels in female mice and decreased glucose tolerance. However, since no obese control animals were used in that study, this finding may have been due to effects secondary to the increased obesity. Furthermore, only intracerebro-ventricular IL-6 injections, but not intraperitoneal IL-6 administration, increased energy expenditure and decreased obesity in these mice, suggesting that the primary target for IL-6 is the central nervous system [25]. In addition, a recent study was unable to confirm that lack of IL-6 was associated with obesity in mice [26].

The present study was designed to investigate the potential acute effects of IL-6 on insulin signalling and action in vivo using the euglycaemic-hyperinsulinaemic clamp, which is considered to be the gold standard to measure insulin sensitivity. No such studies have previously been carried out. To examine the potential role of IL-6 on insulin sensitivity and action, it is necessary to have a steady-state concentration of insulin, against which the potential effect of IL- 6 can be measured. Previous studies of the effects of IL- 6 on glucose metabolism in man have also produced contradictory results $[27,28]$, possibly a consequence of such non-steady-state experimental conditions.

If SOCS-3 plays a critical role, also under normal in vivo conditions, in mediating a reduced effect of insulin following IL-6, this effect should also be seen after 1 to 2 hours of IL-6 infusion when SOCS-3 levels peak. However, our data clearly show that shortterm infusion of IL-6 does not impair the whole-body effect of exogenous insulin on glucose homeostasis or insulin signalling in vivo. These data support other recent findings [11, 29] that IL-6 is predominantly a chronic modulator of insulin action and, in addition, that its effects may be tissue-specific.

\section{Materials and methods}

Animals. We studied 18 female Sprague-Dawley rats (B\&K Universal, Sollentuna, Sweden) for this study. All animals were in oestrus at the time of study to avoid confounding effects of the hormonal cycle. The animals were housed under controlled conditions $\left(21-22{ }^{\circ} \mathrm{C}, 55-65 \%\right.$ humidity and light from 05.00 to 19.00 hours), with five animals in each cage. Animals were allowed to adjust for at least 5 days before initiation of the studies, and were fed a commercial rat chow with sufficient supply of vitamins and minerals, and free access to tap water. The study was approved by the Animal Ethics Committee of Göteborg University, Sweden.

Hyperinsulinaemic-euglycaemic clamp. Prior to the clamp, the animals were anaesthetised intraperitoneally with thiobutabarbital sodium (125 mg/kg body weight; RBI, Natick, Mass., USA).

The euglycaemic-hyperinsulinaemic glucose clamp technique has been described in detail previously [30]. Briefly, catheters were inserted into the left carotid artery for blood sampling and into the right jugular vein for infusion of glucose and insulin. Body temperature was maintained at $37{ }^{\circ} \mathrm{C}$ with a heating blanket. After a bolus injection, insulin (Human Actrapid; Novo Nordisk, Copenhagen, Denmark) was continuously infused at $10 \mathrm{mU} \cdot \mathrm{kg}^{-1} \cdot \mathrm{min}^{-1}$. A $20 \%$ solution of glucose in isotonic saline was also infused to maintain plasma glucose 
levels at $6.0 \mathrm{mmol} / \mathrm{l}$. The IL-6 infusion ( $3 \mu \mathrm{g}$ in total; human recombinant, Sigma, St. Louis, Mo., USA) was initiated with a bolus dose followed by a constant infusion $(5 \mu \mathrm{l} / \mathrm{min})$, which was started at the time of the insulin infusion. Control animals were infused with saline at the same rate. Glucose concentrations were determined at regular intervals (every $5 \mathrm{~min}$ up to $40 \mathrm{~min}$ after initiation and then every $10 \mathrm{~min}$ ). Steady-state glucose levels were reached approximately $40 \mathrm{~min}$ after initiation of the infusions and the glucose infusion rate required to maintain euglycaemia was taken as an index of the glucose disposal rate and, thus, insulin action.

Tail blood pressure and pulse were recorded at 0,90 and 120 min. Blood samples for analyses of insulin, adiponectin, NEFA and IL-6 were taken at 0 and $120 \mathrm{~min}$. A total volume of less than $2 \mathrm{ml}$ was used for these determinations and this was compensated for by the infusion volumes.

The tissues used for gene and protein analyses, i.e. the inguinal adipose tissue, extensor digitorum longus muscle and liver, were taken before the insulin infusion was stopped and were snap-frozen in liquid nitrogen. The tissue was divided into two pieces; one piece was placed in RNA Later for RNA preparation, the other was stored at $-80{ }^{\circ} \mathrm{C}$ for protein analysis.

Analytical methods. Blood was collected in heparinised microtubes and centrifuged immediately. Plasma concentrations of glucose were enzymatically determined in $15-\mu$ samples on a 2700 SELECT biochemical analyser (YSI, Yellow Springs, Ohio, USA).

Plasma insulin was analysed with a rat insulin RIA kit (Linco Research, St. Charles, Mo., USA) and serum NEFA levels were measured using a kit from Wako Chemicals (Neuss, Germany).

Serum IL-6 and adiponectin levels were measured with ELISA techniques (Diaclone, Besancon, France).

Protein analysis. The adipose tissue used for protein analysis was homogenised in lysis buffer containing $50 \mathrm{mmol} / \mathrm{l} \mathrm{HEPES}$, $1 \%$ Triton X, 1\% NP-40, $10 \mathrm{mmol} / \mathrm{l}$ EDTA, $100 \mathrm{mmol} / \mathrm{l}$ sodium fluoride, $100 \mathrm{mmol} / \mathrm{l}$ sodium pyrophosphate, $10 \%$ glycerol, $1 \mathrm{mmol} / \mathrm{l}$ benzamidine, $1.5 \mathrm{mmol} / \mathrm{l}$ aprotinin, $10.5 \mathrm{mmol} / \mathrm{l} \mathrm{leu}-$ peptin, $1 \mu \mathrm{mol} / \mathrm{l}$ okadaic acid and $5 \mathrm{mmol} / 1 \mathrm{Na}_{3} \mathrm{VO}_{4}$. Samples were incubated for $2 \mathrm{~h}$ at $4{ }^{\circ} \mathrm{C}$, centrifuged for $20 \mathrm{~min}$ at $20,000 \mathrm{~g}$ and then kept at $-80{ }^{\circ} \mathrm{C}$ until analysed.

The liver tissue was homogenised in the same lysis buffer, centrifuged at 74,000 $\mathrm{g}$ for $45 \mathrm{~min}$ and the supernatant kept at $-80{ }^{\circ} \mathrm{C}$ until analysed.

The lysis buffer for the muscle tissue contained $50 \mathrm{mmol} / \mathrm{l}$ Tris- $\mathrm{HCl}, 0.1 \%$ Triton $\mathrm{X}, 1 \mathrm{mmol} / \mathrm{l}$ EDTA, $1 \mathrm{mmol} / \mathrm{l}$ EGTA, $50 \mathrm{mmol} / \mathrm{l}$ sodium fluoride, $5 \mathrm{mmol} / \mathrm{l}$ sodium pyrophosphate, $10 \mathrm{mmol} / \mathrm{l}$ glycerophosphate, $1 \mu \mathrm{mol} / \mathrm{l}$ okadaic acid, $1 \mathrm{mmol} / \mathrm{l}$ benzamidine, $100 \mu \mathrm{mol} / \mathrm{l}$ [4-(2-aminoethyl)-bezenesulphonyl fluoride, $\mathrm{HCl}], 0.1 \% \quad \beta$-mercaptoethanol and $1 \mathrm{mmol} / \mathrm{l}$ $\mathrm{Na}_{3} \mathrm{VO}_{4}$. The homogenate was incubated at $+4{ }^{\circ} \mathrm{C}$ for $1.5 \mathrm{~h}$ and centrifuged at $12,000 \mathrm{~g}$ for $15 \mathrm{~min}$. The supernatant was kept at $-80^{\circ} \mathrm{C}$ until analysed.

The protein concentration was measured with bicinchonic acid (Pierce, Rockford, Ill., USA) for fat and liver and the Bradford assay (Bio-Rad Laboratories, Hercules, Calif., USA) was used for the muscle lysate samples.

Lysate proteins were separated on SDS-PAGE as described $[11,31]$ and immunoblotted with anti-phosphotyrosine (Santa Cruz Biotechnology, Santa Cruz, Calif., USA), anti-pY705 STAT3 and anti-STAT3 (Cell Signalling Tech, Beverly, Mass., USA) antibodies according to the recommendations of the manufacturer. Protein blots were scanned using a Personal Densitometer (Molecular Dynamics, Sunnyvale, Calif., USA)
Table 1. Animal body weights, plasma insulin and IL-6 levels at 120 min during the euglycaemic-hyperinsulinaemic clamps

\begin{tabular}{lll}
\hline & Control, $n=9$ & IL-6 infusion, $n=9$ \\
\hline Weight, g & $269 \pm 6$ & $269 \pm 9$ \\
Plasma insulin, mU/1 & $161 \pm 21$ & $126 \pm 22$ \\
Plasma IL-6, nmol/1 & Not determined & $0.85 \pm 0.08$ \\
\hline
\end{tabular}

Insulin was infused at $10 \mathrm{mU} \cdot \mathrm{kg}^{-1} \cdot \mathrm{min}^{-1}$ during the clamps and plasma glucose levels maintained at $6.0 \mathrm{mmol} / \mathrm{l}$

and analysed using Imagequant software provided by the manufacturer.

Where used, arbitrary units refer to intensity units.

RNA extraction and RT-PCR. The adipose tissue was washed with RNAse-free phosphate-buffered saline and homogenised in a solution containing $4 \mathrm{~mol} / \mathrm{l}$ guanidinium thiocyanate, $17 \mathrm{mmol} / \mathrm{l}$ sarkosyl, $25 \mathrm{mmol} / \mathrm{l} \mathrm{Na}$ citrate $\mathrm{pH} 7$ and $0.01 \%$ antifoam A. An equal volume of cold chloroform was added and the sample was shaken vigorously for $1 \mathrm{~min}$ and centrifuged at $12,000 \mathrm{~g}$ at $-4{ }^{\circ} \mathrm{C}$ for $10 \mathrm{~min}$. The water phase was collected and RNA extracted according to Chirgwin et al. [32].

RNA from muscle and liver was extracted using the RNeasy Mini protocol (Qiagen, Hilden, Germany). Muscle tissue was digested with Proteinase K (Sigma) prior to RNA extraction and all samples were treated with DNase I.

We prepared cDNA with TaqMan Reverse Transcription Reagents and the samples were quantified using TaqMan Universal PCR Master Mix and the ABI Prism 7700 Sequence Detection System (Applied Biosystems, Foster City, Calif., USA) using $18 \mathrm{~S}$ as reference as described [33].

Probes and primers for $I L-6, I L-6$ receptor, adiponectin, GLUT4, SOCS-3 and PGC-1 are available upon request.

Statistical analysis. All statistical analyses were performed in Excel and statistical significances evaluated with paired or unpaired, as appropriate, Student's $t$ test. A $p$ value of 0.05 was considered significant.

\section{Results}

Animal characteristics. As shown in Table 1, the animals used in the control and the IL- 6 clamps had the same body weight, and similar insulin levels were reached during the clamps. Circulating IL-6 levels were not measured in the control animals, since an RIA kit recognising only human IL-6 was used. During the IL-6 infusions, high circulating levels were reached $(\sim 1 \mathrm{nmol} / \mathrm{l})$ (Table 1). Blood pressure and heart rates were not changed by the IL-6 infusion (data not shown).

Glucose infusion rate. The glucose infusion rates after 90 to $120 \mathrm{~min}$ of insulin infusion were similar in the control and IL-6 infusion groups (Fig. 1a).

NEFA levels. The insulin infusion reduced circulating NEFA levels in the control group, albeit not significantly, whereas NEFA levels tended to increase in the group receiving the IL-6 infusion ( $p=0.07$ ) (Fig. 1b). 

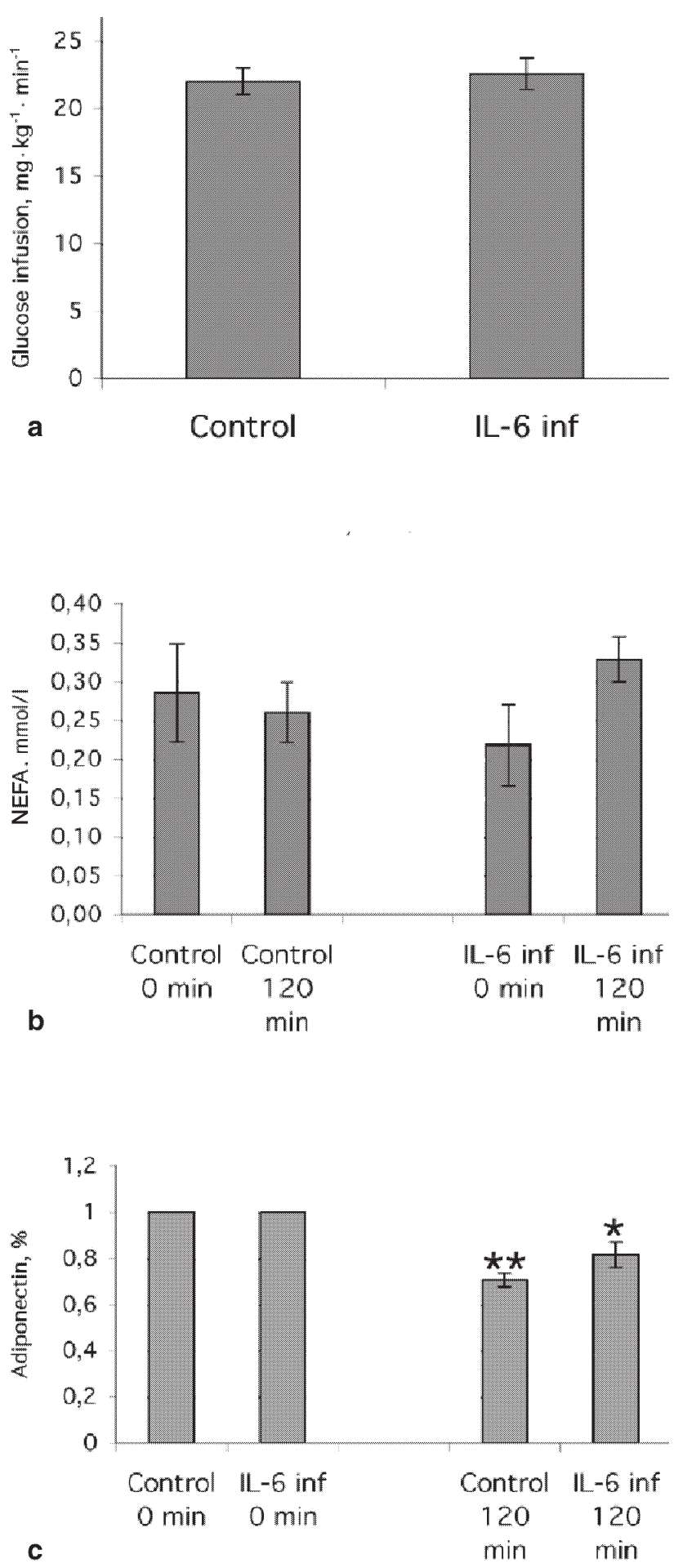

Fig. 1. Glucose infusion rates, plasma NEFA and adiponectin levels during the hyperinsulinaemic-euglycaemic clamps $\left(10 \mathrm{mU} \cdot \mathrm{kg}^{-1} \cdot \mathrm{min}^{-1}\right)$. a. Glucose infusion rate as measured by the amount of glucose required to maintain euglycaemia ( $n=9$ in the saline and IL-6 groups respectively). b. Plasma NEFA concentrations at 0 and $120 \mathrm{~min}(n=9$ in the saline and IL-6 groups respectively). c. Serum adiponectin levels at $120 \mathrm{~min}$ $(n=9$ in the saline and IL-6 groups respectively. $* p<0.05$; $* *$ $p<0.01$
Adiponectin levels. Plasma adiponectin levels decreased significantly both in the control and in the group receiving the IL-6 infusion (Fig. 1c). The numerical decrease (levels before minus levels at $120 \mathrm{~min}$ ) was the same for the two groups of animals, suggesting that it was associated with the increased insulin level during the hyperinsulinaemic-euglycaemic clamp.

Protein expression and tyrosine phosphorylation. STAT3 tyrosine phosphorylation was increased in the fat, muscle and liver of the rats receiving the IL-6 infusion, showing that the IL-6 signalling system was activated in all tissues (Fig. 2a-c).

There was no consistent difference in the tyrosine phosphorylation (or protein expression, data not shown) of the insulin receptor or the insulin receptor substrates (Fig. 2a-c), showing that IL-6 does not acutely change insulin signalling in vivo under these experimental conditions. This is in accordance with the data for the glucose infusion rates (Fig. 1a).

Gene expression. We also investigated the potential effect of the IL-6 infusion on gene expression of several molecules involved in IL-6 and insulin signalling and action. IL-6 gene expression did not increase significantly in fat and liver, but tended to be increased in muscle ( $p=0.08$; Fig. 3a). IL-6 receptor mRNA was not changed in any of the three tissues, nor was GLUT4 or PGC-1 (data not shown). SOCS-3 gene expression was significantly increased in muscle and liver of the IL- 6 + insulin infusion group, when compared to insulin alone (Fig. 3b). Adiponectin mRNA levels in the adipose tissue were not significantly altered by infusing IL- 6 and insulin as compared to insulin alone (Fig. 3c).

\section{Discussion}

The present study was designed to investigate if IL-6 rapidly (within $120 \mathrm{~min}$ ) inhibits the effect of a sustained hyperinsulinaemia on glucose homeostasis in vivo. To this end, the rats were infused with IL- 6 or saline for 120 min during a euglycaemic and hyperinsulinaemic clamp. This design was used in order to examine the in vivo effects of the increased SOCS-3 levels in the target tissues for insulin. Previous detailed studies in vitro $[17,18]$ have shown that the intracellular signalling for insulin is decreased in liver cells in parallel with increased SOCS-3 levels. However, it has not been previously examined whether this perturbation is sufficient to produce insulin resistance in vivo. Somewhat surprisingly, insulin has also been shown to increase SOCS-3 levels in adipose tissue, liver and skeletal muscle to a similar extent as IL-6 and with a similar time-course [20]. Thus, it has been suggested that SOCS-3 may also play a role in modu- 
a

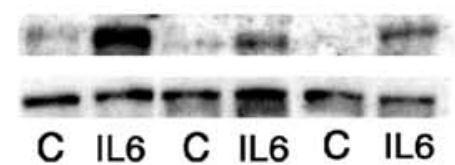

pSTAT3

STAT3

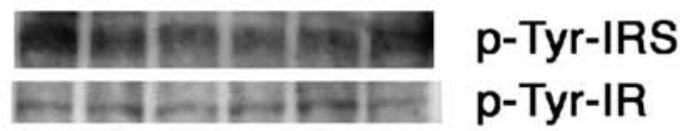

C IL6 C IL6 C IL6
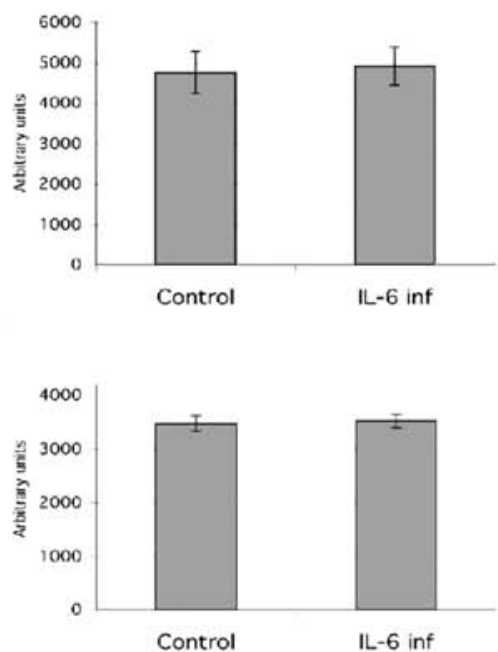

c

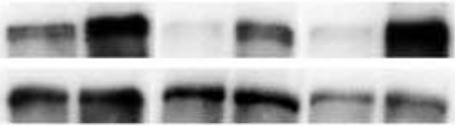

C IL6 C IL6 C IL6

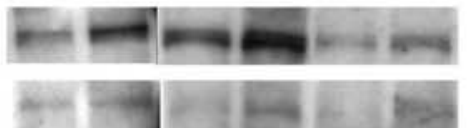

p-Tyr-IRS

p-Tyr-IR

C IL6 C IL6 C IL6

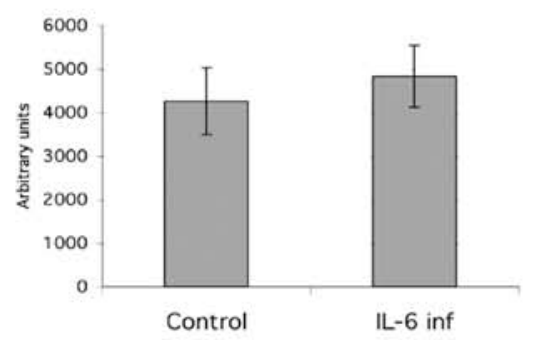

p-Tyr-IRS

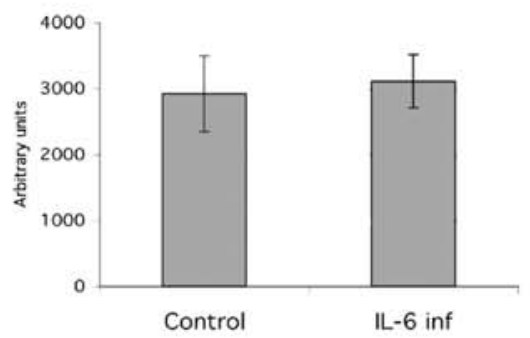

p-Tyr-IR

pSTAT3

STAT3

p-Tyr-IR b
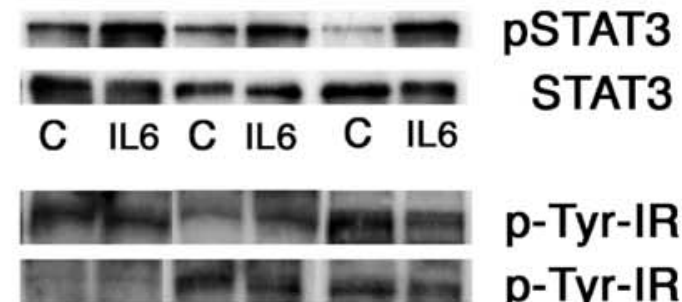

p-Tyr-IRS

C IL6 C IL6 $\quad$ C IL6

p-Tyr-IR

p-Tyr-IRS

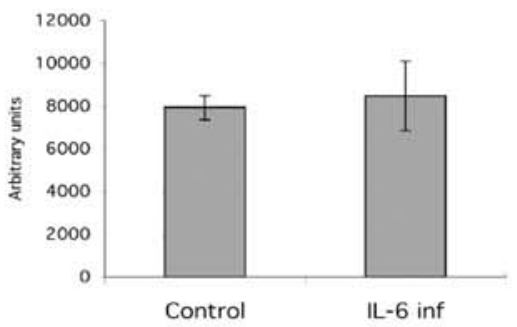

p-Tyr-IR

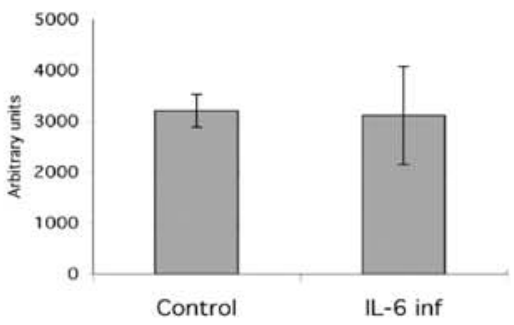

Fig. 2. Insulin and IL-6 signalling molecules in muscle (a), liver (b) and adipose tissue (c) following the hyperinsulinaemic-euglycaemic clamps. Tyrosine phosphorylation ( $\mathrm{pY}$ site 705) of STAT3, STAT3 protein and tyrosine phosphorylation (p-Tyr) of IRS and the insulin receptors (IR). Scanned data for (a) muscle $(n=4)$, (b) liver $(n=4)$, (c) adipose tissue $(n=7)$. Results are shown as means \pm SEM 
a Muscle

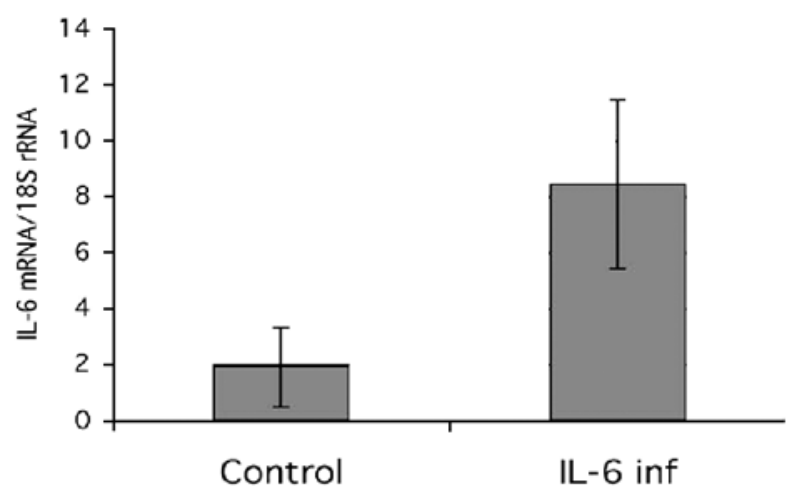

\section{Liver}

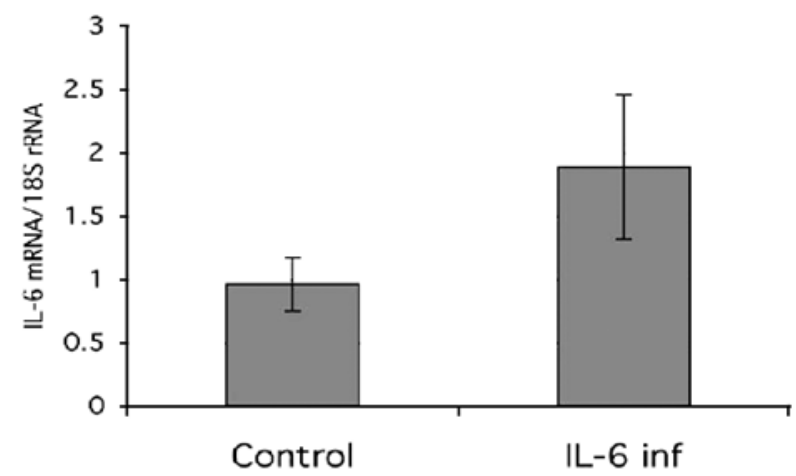

Fat

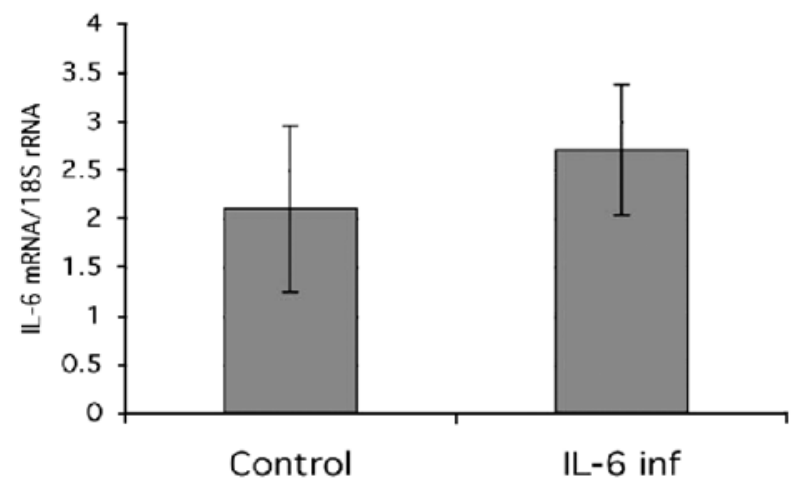

\section{Fat}

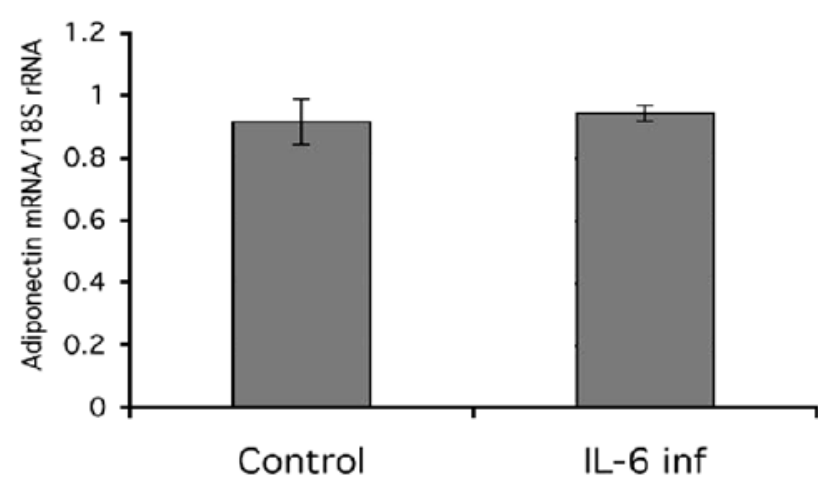

\section{b Muscle}

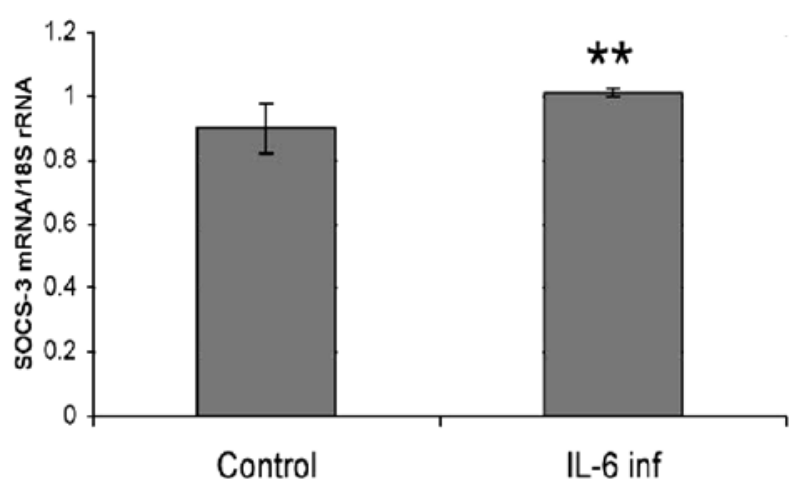

Liver

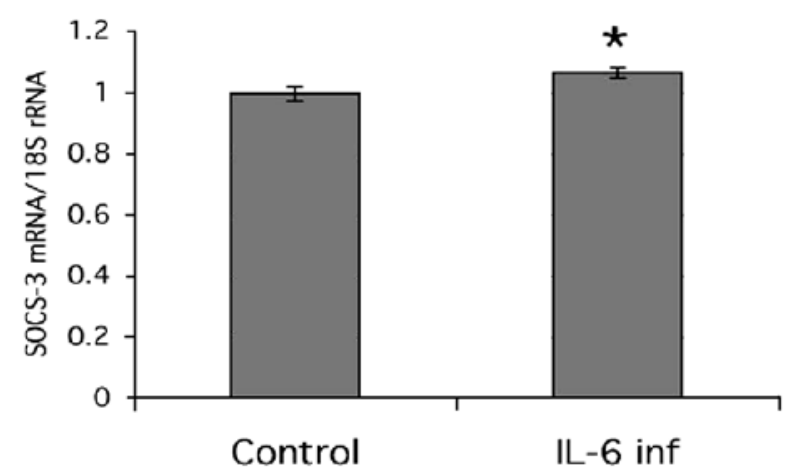

Fat

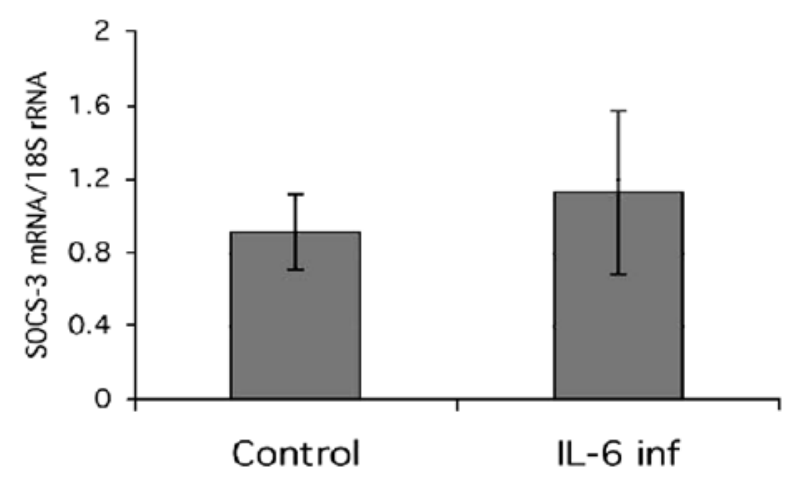

Fig. 3. IL-6 (a) and SOCS-3 (b) mRNA levels in muscle, liver and adipose tissue, and adiponectin (c) mRNA levels in adipose tissue, as determined after the hyperinsulinaemic-euglycaemic clamps using $18 \mathrm{~S}$ as reference. Results are means \pm SEM for 9 rats in each group. $* p<0.05 ; * * p<0.01$ 
lating insulin sensitivity following chronic hyperinsulinaemia [20].

The present data clearly show that a short-term infusion of IL-6 does not impair the effects of insulin on whole-body glucose disposal in vivo. This is in agreement with previous studies in man, showing a modest or no effect of IL-6 on glucose levels in vivo in the absence of defined hyperinsulinaemia [27, 28, 34].

The fact that the target tissues (adipose cells, skeletal muscle and liver) had activated the intracellular IL-6 signalling cascade is shown by the increased tyrosine phosphorylation of STAT3, a key inducer of the intracellular actions of IL-6 [35]. In agreement with the lack of effect on whole-body insulin action and on glucose disposal, we found no significant or consistent reductions in the tyrosine phosphorylation of the insulin receptors or the IRS molecules. A potential problem for this, however, is that we examined the tyrosine phosphorylation of these molecules as induced by the insulin infusion in vivo. This leads to a greater variability than that seen in in vitro incubations and, thus it may not have been possible to identify minor changes. However, even if this were the case, the variability was small enough not to be associated with whole-body insulin resistance following the IL-6 infusion.

Another potential caveat is that we used a high physiological insulin concentration during the clamps. This may have compensated for a small impairment in insulin action in the liver and adipose tissue considering their normal high sensitivity to insulin. On the other hand, the IL-6 infusions produced $\sim 3$ to 400 -fold higher plasma concentrations than those normally seen in rats and man $[24,36]$ and this would favour any potential early inhibitory effects of IL-6. Such concentrations of IL-6 may, in fact, not be unphysiological at the cellular level in vivo, at least in tissues producing IL-6 such as the adipose tissue and the muscle tissue following exercise [37]. We recently measured the interstitial IL-6 concentrations in human adipose tissue in situ using a calibrated microdialysis technique and found concentrations similar to those reached in plasma in the present study [24].

There were only minor or no changes in the genes measured after $120 \mathrm{~min}$ : GLUT4, PGC-1, adiponectin, $I L-6$ or SOCS-3. This may well have been expected considering the short infusion time. However, it must be emphasised that the experimental design only makes it possible to examine effects of IL- 6 that are additional to those of insulin itself, since all animals were infused with insulin (and saline or IL-6). This is the most likely reason for the small difference in SOCS-3 gene expression following IL-6, since insulin also increases SOCS-3 mRNA levels to a similar extent as IL-6 and with a similar time-course [20]. The present study, then, suggests that there is no additive or synergistic effect of these hormones under the present experimental conditions.
We [11] and others [16] have previously found that long-term exposure ( 24 or $48 \mathrm{~h}$ ) of adipocytes to IL-6 increases IL-6 mRNA levels 4 to 6-fold. In the present short-term study, this was most evident in the skeletal muscle but the physiological consequence of this is currently unclear.

There were only minor changes in NEFA levels in the two groups of animals, although the levels tended to increase following IL-6 infusion. The small antilipolytic effect of insulin may appear surprising but hyperinsulinaemic clamps in non-obese rodents are frequently associated with a minor suppression of NEFA, possibly due to an activation of the sympathetic nervous system. Importantly, however, the circulation in the animals was not compromised, since blood pressure and heart rates remained unchanged during the study.

The available data on the effect of IL- 6 on lipolysis is contradictory. IL-6 has been found to reduce lipoprotein lipase activity in the adipose tissue in vivo as well as in 3T3-L1 adipocytes in vitro [38]. It has also been reported that IL-6 stimulated lipolysis in rats [39] and in man [40, 41], whereas no such effect of IL-6 has been found in other studies [42, 43].

Plasma adiponectin levels decreased significantly both in control and in IL-6 treated rats, but the extent of the decrease did not differ between the two groups, suggesting that it was due to the hyperinsulinaemic clamp rather than to IL-6. This was further supported by the findings that there was no difference in adiponectin mRNA levels in the adipose tissue between the two groups where insulin is the common denominator. Hyperinsulinaemic clamps have also previously been shown to lead to decreased serum adiponectin levels in human subjects $[44,45]$ as well as in monkeys [46] and plasma adiponectin levels correlate negatively with fasting insulin levels [47, 48, 49].

In conclusion, infusion of IL-6 for $120 \mathrm{~min}$ in rats during hyperinsulinaemic and euglycaemic conditions did not impair the effect of insulin on whole-body glucose homeostasis in vivo. Furthermore, no short-term effect of IL-6 was found on plasma adiponectin levels or on insulin signalling in adipose tissue, muscle or liver in vivo. These results do not support the idea that SOCS-3 is an important mediator of insulin resistance under in vivo conditions. In contrast, chronically elevated IL-6 levels exert inhibitory effects on insulin signalling and action by suppressing the gene transcription of several important molecules $[11,16]$. It is also possible that IL-6 exerts tissue-specific effects $[24,29]$ and that the major targets for cross-talk between IL- 6 and insulin may be the adipose tissue and the liver rather than the skeletal muscle.

Acknowledgements. This study was supported by grants from the Swedish Research Council (K2004-72X-03506-33A and 12206), the Torsten and Ragnar Söderberg Foundations, the European Community (QLG1-1999-CT-00674), the Swedish 
Diabetes Association, the Sonya Hedenbratt Memorial Fund, the Inga Britt and Arne Lundberg Foundation and the NovoNordisk Foundation.

\section{References}

1. Fey GH, Hattori M, Hocke G et al. (1991) Gene regulation by interleukin 6 . Biochimie 73:47-50

2. Hirano T (1998) Interleukin 6 and its receptor: ten years later. Int Rev Immunol 16:249-284

3. Mohamed-Ali V, Goodrick S, Rawesh A et al. (1997) Subcutaneous adipose tissue releases interleukin-6, but not tumor necrosis factor-alpha, in vivo. J Clin Endocrinol Metab 82:4196-4200

4. Fernandez-Real JM, Vayreda M, Richart C et al. (2001) Circulating interleukin 6 levels, blood pressure, and insulin sensitivity in apparently healthy men and women. J Clin Endocrinol Metab 86:1154-1159

5. Muller S, Martin S, Koenig W et al. (2002) Impaired glucose tolerance is associated with increased serum concentrations of interleukin 6 and co-regulated acute-phase proteins but not TNF-alpha or its receptors. Diabetologia 45:805-812

6. Pickup JC, Mattock MB, Chusney GD, Burt D (1997) NIDDM as a disease of the innate immune system: association of acute-phase reactants and interleukin- 6 with metabolic syndrome X. Diabetologia 40:1286-1292

7. Kado S, Nagase T, Nagata N (1999) Circulating levels of interleukin-6, its soluble receptor and interleukin-6/interleukin-6 receptor complexes in patients with type 2 diabetes mellitus. Acta Diabetol 36:67-72

8. Pradhan AD, Manson JE, Rifai N, Buring JE, Ridker PM (2001) C-reactive protein, interleukin 6, and risk of developing type 2 diabetes mellitus. JAMA 286:327-334

9. Fried SK, Bunkin DA, Greenberg AS (1998) Omental and subcutaneous adipose tissues of obese subjects release interleukin-6: depot difference and regulation by glucocorticoid. J Clin Endocrinol Metab 83:847-850

10. Path G, Bornstein SR, Gurniak M et al. (2001) Human breast adipocytes express interleukin-6 (IL-6) and its receptor system: increased IL-6 production by beta-adrenergic activation and effects of IL-6 on adipocyte function. J Clin Endocrinol Metab 86:2281-2288

11. Rotter V, Nagaev I, Smith U (2003) Interleukin-6 (IL-6) induces insulin resistance in 3T3-L1 adipocytes and is, like IL-8 and tumor necrosis factor-alpha, overexpressed in human fat cells from insulin-resistant subjects. J Biol Chem 278:45777-45784

12. Kim H, Baumann H (1999) Dual signaling role of the protein tyrosine phosphatase SHP-2 in regulating expression of acute-phase plasma proteins by interleukin- 6 cytokine receptors in hepatic cells. Mol Cell Biol 19:5326-5338

13. Campbell JS, Prichard L, Schaper F et al. (2001) Expression of suppressors of cytokine signaling during liver regeneration. J Clin Invest 107:1285-1292

14. Kami K, Morikawa Y, Sekimoto M, Senba E (2000) Gene expression of receptors for IL-6, LIF, and CNTF in regenerating skeletal muscles. J Histochem Cytochem 48: 1203-1213

15. Kunisada K, Tone E, Fujio Y et al. (1998) Activation of gp130 transduces hypertrophic signals via STAT3 in cardiac myocytes. Circulation 98:346-352

16. Lagathu C, Bastard JP, Auclair M et al. (2003) Chronic interleukin-6 (IL-6) treatment increased IL-6 secretion and induced insulin resistance in adipocyte: prevention by rosiglitazone. Biochem Biophys Res Commun 311: 372-379

17. Senn JJ, Klover PJ, Nowak IA, Mooney RA (2002) Interleukin-6 induces cellular insulin resistance in hepatocytes. Diabetes 51:3391-3399

18. Senn JJ, Klover PJ, Nowak IA et al. (2003) Suppressor of cytokine signaling-3 (SOCS-3), a potential mediator of interleukin-6-dependent insulin resistance in hepatocytes. J Biol Chem 278:13740-13746

19. Lieskovska J, Guo D, Derman E (2003) Growth impairment in IL-6-overexpressing transgenic mice is associated with induction of SOCS3 mRNA. Growth Horm IGF Res 13:26-35

20. Emanuelli B, Peraldi P, Filloux C et al. (2001) SOCS-3 inhibits insulin signaling and is up-regulated in response to tumor necrosis factor-alpha in the adipose tissue of obese mice. J Biol Chem 276:47944-47949

21. Rui L, Yuan M, Frantz D, Shoelson S, White MF (2002) SOCS-1 and SOCS-3 block insulin signaling by ubiquitinmediated degradation of IRS1 and IRS2. J Biol Chem 277:42394-42398

22. Fasshauer M, Kralisch S, Klier M et al. (2003) Adiponectin gene expression and secretion is inhibited by interleukin-6 in 3T3-L1 adipocytes. Biochem Biophys Res Commun 301:1045-1050

23. Gustafson B, Jack MM, Cushman SW, Smith U (2003) Adiponectin gene activation by thiazolidinediones requires PPARgamma2, but not C/EBPalpha-evidence for differential regulation of the $\mathrm{aP} 2$ and adiponectin genes. Biochem Biophys Res Commun 308:933-939

24. Sopasakis VR, Sandqvist M, Gustafson B et al. (2004) High local concentrations and effects on differentiation implicate interleukin-6 as a paracrine regulator. Obes Res 12: 454-460

25. Wallenius V, Wallenius K, Ahren B et al. (2002) Interleukin-6-deficient mice develop mature-onset obesity. Nat Med 8:75-79

26. Di Gregorio GB, Hensley L, Lu T, Ranganathan G, Kern PA (2004) Lipid and carbohydrate metabolism in mice with a targeted mutation in the IL-6 gene: absence of development of age-related obesity. Am J Physiol Endocrinol Metab 287:E182-E187

27. Tsigos C, Papanicolaou DA, Kyrou I et al. (1997) Dosedependent effects of recombinant human interleukin-6 on glucose regulation. J Clin Endocrinol Metab 82:4167-4170

28. Steensberg A, Fischer CP, Sacchetti M et al. (2003) Acute interleukin-6 administration does not impair muscle glucose uptake or whole-body glucose disposal in healthy humans. J Physiol 548:631-638

29. Klover PJ, Zimmers TA, Koniaris LG, Mooney RA (2003) Chronic exposure to interleukin-6 causes hepatic insulin resistance in mice. Diabetes 52:2784-2789

30. Holmang A, Svedberg J, Jennische E, Bjorntorp P (1990) Effects of testosterone on muscle insulin sensitivity and morphology in female rats. Am J Physiol 259:E555-E560

31. Carvalho E, Jansson PA, Axelsen M et al. (1999) Low cellular IRS 1 gene and protein expression predict insulin resistance and NIDDM. FASEB J 13:2173-2178

32. Chirgwin JM, Przybyla AE, MacDonald RJ, Rutter WJ (1979) Isolation of biologically active ribonucleic acid from sources enriched in ribonuclease. Biochemistry 18:5294-5299

33. Carvalho E, Jansson PA, Nagaev I, Wenthzel AM, Smith U (2001) Insulin resistance with low cellular IRS-1 expression is also associated with low GLUT4 expression and impaired insulin-stimulated glucose transport. FASEB J 15: 1101-1103 
34. Stouthard JM, Romijn JA, Van der Poll T et al. (1995) Endocrinologic and metabolic effects of interleukin-6 in humans. Am J Physiol 268:E813-E819

35. Heinrich PC, Behrmann I, Muller-Newen G, Schaper F, Graeve L (1998) Interleukin-6-type cytokine signalling through the gp130/Jak/STAT pathway. Biochem J 334: 297-314

36. Mitnick MA, Grey A, Masiukiewicz U et al. (2001) Parathyroid hormone induces hepatic production of bioactive interleukin-6 and its soluble receptor. Am J Physiol Endocrinol Metab 280:E405-E412

37. Keller P, Keller C, Carey AL et al. (2003) Interleukin-6 production by contracting human skeletal muscle: autocrine regulation by IL-6. Biochem Biophys Res Commun 310:550-554

38. Greenberg AS, Nordan RP, McIntosh J et al. (1992) Interleukin 6 reduces lipoprotein lipase activity in adipose tissue of mice in vivo and in 3T3-L1 adipocytes: a possible role for interleukin 6 in cancer cachexia. Cancer Res 52:4113-4116

39. Nonogaki K, Fuller GM, Fuentes NL et al. (1995) Interleukin-6 stimulates hepatic triglyceride secretion in rats. Endocrinology 136:2143-2149

40. Pedersen BK, Steensberg A, Keller P et al. (2003) Musclederived interleukin-6: lipolytic, anti-inflammatory and immune regulatory effects. Pflugers Arch 446:9-16

41. van Hall G, Steensberg A, Sacchetti M et al. (2003) Interleukin-6 stimulates lipolysis and fat oxidation in humans. J Clin Endocrinol Metab 88:3005-3010

42. Orban Z, Remaley AT, Sampson M, Trajanoski Z, Chrousos GP (1999) The differential effect of food intake and beta-adrenergic stimulation on adipose-derived hor- mones and cytokines in man. J Clin Endocrinol Metab $84: 2126-2133$

43. Feingold KR, Doerrler W, Dinarello CA, Fiers W, Grunfeld C (1992) Stimulation of lipolysis in cultured fat cells by tumor necrosis factor, interleukin-1, and the interferons is blocked by inhibition of prostaglandin synthesis. Endocrinology 130:10-16

44. Lihn AS, Ostergard T, Nyholm B et al. (2003) Adiponectin expression in adipose tissue is reduced in first-degree relatives of type 2 diabetic patients. Am J Physiol Endocrinol Metab 284:E443-E448

45. Mohlig M, Wegewitz U, Osterhoff M et al. (2002) Insulin decreases human adiponectin plasma levels. Horm Metab Res 34:655-658

46. Hotta K, Funahashi T, Bodkin NL et al. (2001) Circulating concentrations of the adipocyte protein adiponectin are decreased in parallel with reduced insulin sensitivity during the progression to type 2 diabetes in rhesus monkeys. Diabetes 50:1126-1133

47. Hotta K, Funahashi T, Arita Y et al. (2000) Plasma concentrations of a novel, adipose-specific protein, adiponectin, in type 2 diabetic patients. Arterioscler Thromb Vasc Biol 20:1595-1599

48. Weyer C, Funahashi T, Tanaka S et al. (2001) Hypoadiponectinemia in obesity and type 2 diabetes: close association with insulin resistance and hyperinsulinemia. J Clin Endocrinol Metab 86:1930-1935

49. Pellme F, Smith U, Funahashi T et al. (2003) Circulating adiponectin levels are reduced in nonobese but insulinresistant first-degree relatives of type 2 diabetic patients. Diabetes 52:1182-1186 